Article

\title{
Asserting the Vernacular: Contested Musealities and Contemporary Art in Lima, Peru
}

\author{
Gabriela Germana ${ }^{1,2, *}$ and Amy Bowman-McElhone ${ }^{2,3, *}$ \\ 1 School of Art \& Art History, University of South Florida, Tampa, FL 33620, USA \\ 2 Department of Art History, Florida State University, Tallahassee, FL 32304, USA \\ 3 Art Program, Carlow University, Pittsburgh, PA 15213, USA \\ * Correspondence: ggermanar@gmail.com (G.G.); amybowman82@gmail.com (A.B.-M.)
}

Received: 1 October 2019; Accepted: 16 January 2020; Published: 7 February 2020

\begin{abstract}
This essay examines three museums of contemporary art in Lima, Peru: MAC (Museum of Contemporary Art), MALI (Lima Art Museum), and MASM (San Marcos Art Museum). As framed through curatorial studies and cultural politics, we argue that the curatorial practices of these institutions are embedded with tensions linked to the negotiation of regional, national, and international identities, coloniality, and alternate modernities between Western paradigms of contemporary art and contemporary vernacular art in Peru. Peruvian national institutions have not engaged in the collection of contemporary art, leaving these practices to private entities such as the MAC, MALI, and MASM. However, these three institutions have not, until recently, actively collected contemporary vernacular Peruvian art and its by-products, thus inscribing this work as "non-Western" through curatorial practices and creating competing conceptions of the contemporary. The curatorial practices of the MAC, MALI, and MASM reflect the complex and contested musealities and conceptions of the contemporary that co-exist in Lima. This essay will address this environment and the emergence of alternative forms of museality, curatorial practices, and indigenous artist's strategies that continually construct and disrupt different modernities and create spaces for questioning constructs of contemporary art and Peruvian cultural identities.
\end{abstract}

Keywords: Peruvian art; contemporary art; indigenous art; museums; curatorial practices; alternative musealities; decoloniality; Lima; Andes; Amazonia

\section{Introduction}

In 2016, Peruvian curator Gustavo Buntinx mapped an alternate history of Peruvian contemporary art via artist and curator projects that presented alternative modes of display and transgressive musealities in his exhibition, Museum Void: Half a Century of Peruvian Museotopies. The exhibition, which dealt with the institutional void for the display and cultivation of Peruvian contemporary art in Lima, was presented in the Contemporary Art Museum of Lima (MAC) that recently opened in 2013. Prior to the MAC, few institutions in Peru, national or private, consistently devoted its mission to the collection, study, and display of contemporary art with the exception of the aforementioned MAC, the MALI (Lima Art Museum), and the MASM (San Marcos Art Museum). These organizations, as well as paradigmatic events such as the international art fairs "Art Lima" and "Peru Arte Contemporaneo" (PARC), which are all located in the capital city of Lima, have shaped the dominant conception of contemporary art in Peru in the twenty-first century within Western paradigms that are rooted in the colonial histories of the country. However, indigenous and vernacular artists are attending to these conditions and subverting them in unique and dynamic ways that are based on their lived experiences and cultural contexts. In doing so, these artists are shifting the established art system in Peru by producing their own modern and contemporary forms of art and negotiating their participation in Peruvian cultural 
institutions as in other fields of contemporary life. Furthermore, curators such as Buntinx are building new institutional frameworks through the production of alternative musealities within the voids left by the material lack of a Western-museum model that effectively attends to contemporary art within Peru. This void is due, in part, to the fundamental incompatibility of a monolithic Eurocentric paradigm of aesthetic values with Peruvian alternative modernities and contemporaneities.

Since the nineteenth century, the categories of art in Peru have followed the paradigms of Eurocentric modernity that were disseminated through art institutions shaped by colonialism, museums, schools of fine arts, the art market, and have established Western aesthetic hierarchies of what is and what is not art, what should be included and what should be ignored. Artists formally trained and based in urban environments were, and are, privileged in these contexts. However, there are parallel modes of artistic production by rural and vernacular artists that are distinct and vital and have not been, until recently, considered by the Peruvian system of modern and contemporary art. As a result, contemporary indigenous and vernacular Peruvian art is sited outside of this construct resulting in multiple contemporaneities within Peruvian, and specifically Limeño visual culture.

These contemporaneities emerged through the scrambling of rural and urban binaries, especially in the second half of the twentieth century, when the configuration of Peruvian society changed dramatically. Since the beginning of the twentieth century, modernization projects lead by the urban elites, under the modernity's narrative of economic growth and progress, changed rural societies and in many situations, rural inhabitants themselves, convinced that modernization was a way to solve their problems, demanded projects of modernization for their communities (Contreras and Cueto 2013, p. 279). Since the 1960s, significant groups of rural inhabitants were forced to move to the large cities in Peru, especially to the capital city of Lima, initially due to the economic crisis and later because of the violence unleashed by the internal armed conflict. ${ }^{1}$ These dynamics activated complex processes that resulted in renewed forms of modernity. ${ }^{2}$ Given the inability of the State to generate development programs tailored to these new needs, migrants organized themselves to meet the urgencies of survival and social recognition, creating parallel structures in areas such as the economy, politics, education, and religion, based on the cultural models of their places of origin. ${ }^{3}$ In this way, a series of cultural, social and economic organizational patterns established by the State and the ruling elites since the nineteenth century, the ones that were considered modern, were contested and radically transformed. These

1 The Peruvian Internal Armed Conflict began with the self-declared armed struggle of the Shining Path against the government. The response of the government to the subversive groups also reached extreme violence. According to the Comisión de la Verdad y la Reconciliación (CVR), the conflict took an estimated of 69,230 lives, victims of the crossfire between the subversive terrorist groups and the Peruvian Armed Forces. The most affected areas were the rural and poorest communities located in the central-southern region of Peru.

2 Peruvian sociologist Sinesio López refers to this phenomena in terms in citizenship formation: "No existe una historia única de la ciudadanía en el mundo moderno. Su emergencia y desarrollo no siguen un único patrón ni asumen la misma forma. Ni el punto de partida, ni el proceso, ni los resultados son idénticos. Los estudios actuales de la ciudadanía han llegado a la conclusión de que existen varios patrones de formación ciudadana ( . . ) que ( . . ) presentan, a su vez, diversas variantes provenientes de las peculiaridades de cada país" [There is no single history of citizenship in the modern world. Its emergence and development do not follow a single pattern or assume the same form. Neither the starting point, nor the process, nor the results are identical. Current studies of citizenship have concluded that there are several patterns of citizen formation (...) that (...) present, in turn, various variants from the peculiarities of each country] (López 1997, p. 81, our translation).

3 In a pioneer study about internal migration in Peru, sociologist Aníbal Quijano points out the emergence of a new socio-cultural group "cholo" as a result of the impact of modernization on the traditional rural segments of Peruvian society. However, Quijano states, under the conditions of capitalist development, this group does not fully integrate into the "modernized" or "urban" sector of society, constituting, rather, a "transitional culture" that integrates elements of ancient Andean roots -discipline, solidarity, community sense- with those of capitalist societies, the market and urban growth (Quijano 1980). In another fundamental text, anthropologist José Matos Mar addresses the existence of two Peru, one formal—characterized by the presence of the State-and an informal one that represents the marginalized country. This conformation, inherited from the colonial times, begins to show the first symptoms of problems at the end of the 19 th century. The deepest transformations, however, occur in the second half of the twentieth century with the accelerated development of communications, changes in the economy, agrarian reform, the expansion of the internal market and the migratory explosion from the countryside to the city. The Andean culture, marginalized until that moment, carried out powerful invasions, not only literally of the urban estates, but in the various instances of the official culture, imposing their new styles (Matos Mar 1984). 
processes can be framed by what postcolonial and decolonial studies have referred to as "alternative modernities". Rather than conceiving a single modernity based on a model imposed by the West and merely consumed by other parts of the world when it arrives, "alternative modernities", which does not discount Western discourses on modernity since Western expansion is a fact, takes into account how people in each place are creators of their own modernity, and how, at each site, the elements proposed by modernity are put together in a unique way in response to local culture and politics. ${ }^{4}$ Scholar Dilip Parameshwar Gaonkar names this phenomenon as site-specific "creative adaptations" to articulate that "It does not mean that one can freely choose whatever one likes from the offerings of modernity (... ); rather, it points to the manifold ways in which people question the present. It is the site where people "make" themselves modern, as opposed to being "made" modern by alien and impersonal forces, and where they give themselves an identity and a destiny" (Gaonkar 1999, p. 16).

These dynamics manifested in visual culture as well and new artistic creations emerged in line with the identities of migrant groups: There are vernacular artists who continue producing objects, although new, transformed versions of old ones, for their communities or the rural, regional markets, visual culture that is produced in the cities for the consumption of migrants, objects produced for the tourist market, objects produced for the urban public, among many other variants. Through multiple contemporaneities, new forms of visual expression were generated, which responded to the intense, persistent, and dynamic dialogue between regional practices and aesthetics, and manifestations of Western cosmopolitan culture. While the contemporary art system needs to address these different, parallel modernities in contemporary art production in Peru to avoid maintaining colonial patterns for determining aesthetic values where inclusion is not determined by Eurocentric paradigms, it is not a one-way dynamic. There is a complex negotiation by indigenous artists of the cultural categories applied to their work and a more generalized demand, by curatorial agents, for their participation in Peruvian cultural institutionality.

In this context, alternative musealities are critical to amplifying the negotiations by indigenous and vernacular artists in producing "sideways" and forward movements, as Gaonkar asserts, in visual art and culture. The term museality has developed within international museum studies discourses. It is nested within the larger concept of the museal alongside the terminology of musealia and musealization. Largely, the museal and museality comprise a theoretical field that refers to "the characteristic of something that in one reality documents another reality" (Latham 2017, p. 226). This theoretical framework invites a transdisciplinary interrogation of museum and curatorial practices as a form of knowledge production that, in many cases, powerfully reproduces colonial logic. In the case of Peru, indigenous and vernacular artists and their distinct forms of knowledge have been eased, overwritten, and excluded from categories of the contemporary. Here, we propose that there are multiple musealities, such as there are multiple modernities and contemporaneities, that are in fact "creative adaptations" driven by indigenous and vernacular artists and independent curators. These "creative adaptations" produce multiple musealities by reconfiguring the documentation of specific cultural realities that make indigenous communities and their forms of cultural knowledge legible within institutional contexts. This, in turn, creates new categories of the contemporary through

4 While postcolonial and decolonial studies both seek to contest the colonial world order and the epistemological dominance established by European empires, they originated from a different set of theoretical frames and from different geographical regions. Postcolonial theories emerged from the experience of British colonization in Middle Eastern and South Asian regions. Its purpose "is more about re-inscribing 'other' cultural traditions into narratives of modernity and thus transforming those narratives-both in historical terms and theoretical ones-rather than simply renaming or re-evaluating the content of these other 'inheritances'" (Bhambra 2014, p. 116). It is in this context that the notion of "alternative modernities" was developed. Decoloniality, on the other hand, emerged from the colonial experience in South America, and its aim is to confront and delink from coloniality and its rhetoric of modernity. Although from the perspective of decolonial theories, the concept of "alternative modernities" can be disputed, because it still has Western modernity as a point of reference (Mignolo 2011b, pp. XXVIII-XXIX), decoloniality deals with the way colonized people have appropriated the colonial impositions to reflect their unique perspectives, thus pursuing their own modernity (Mignolo 2011a, p. 134). On alternative, different modernities, see (Chatarjee 1997; Gaonkar 1999; Mignolo 2011a). 
artistic and curatorial production whereby artists and curators, in Gaonkar's terms, give "themselves an identity and a destiny".

In this article, we will begin by addressing the collecting and curatorial practices of the MAC, MALI, and MASM and the ways in which they have, until recently, enacted colonial hierarchies in the field of Peruvian contemporary art. We will assess how these hierarchies are legitimized in the global art system, specifically through the category of contemporary Latin American art and its use in the United States. We will also analyze the role played by the Peruvian state, which consolidates the hierarchies established by the art system, and has deployed vernacular and indigenous arts as referents of a national identity that are concurrently associated with categories of tourist and popular art. Next, we will articulate how indigenous and vernacular artists, immersed in multiple and different contemporaneities, are continually disrupting and negotiating the categories established by the art system and the Peruvian state while proposing their own artistic modernities. Ultimately, we will assert that critical producers of indigenous and vernacular art in Peru, both artists, and curators, have served as agents of decolonization by shifting the curatorial practices of Peruvian museums towards a presentation of art that recognizes and internalizes the complex identities and contours of Peruvian cultural production, specifically articulating histories of alternative modernities and amplifying multiple contemporaneities unique to Peru that run counter to narratives of monolithic Western modernism and Eurocentric frameworks for global contemporary art. As such, artists and curators have crafted alternative musealities that articulate and witness the specificities of Peruvian reality by introducing new epistemologies rooted in indigeneity that reconfigures colonial logics in productive ways.

\section{The Contemporary Art System and the Museums in Lima: MALI, MAC, MASM}

In Peru, the interrelationship of collecting and curatorial practices of the MAC, MALI, and MASM and the international art fairs such as "Art Lima" and PARC, have cultivated a class of transnational Peruvian collectors, curators, and artists that are practicing within a global framework of contemporary art. As such, this network of market and museum institutions has inscribed contemporary art in Peru within Western paradigms. For instance, the MALI, a private museum founded in 1961, had focused on historical Peruvian art for most of its history. In the late 1990s, the museum deliberately reoriented itself towards contemporary art under new leadership and a younger, more engaged board of directors. The museum achieved this pivot by launching a series of initiatives that included the creation, in 2007, of the position of Curator of Contemporary Art and the establishment of the Acquisition Committee for Contemporary Art (CAAC). ${ }^{5}$ The CAAC was modeled on the Tate Modern's system in London, and functions, according to Peruvian anthropologist Giuliana Borea, as a learning apparatus for developing transnationally-oriented Peruvian collectors schooled within the context of internationally-positioned Western museums. The MALI's initiatives have resulted in Lima's strategic placement as a critical urban node in the global contemporary art arena as well as a city that promotes the transnational category of Latin American art within international contemporary art and museum networks (Borea 2016, pp. 318-19).

In contrast, the MASM (San Marcos Art Museum) is a state institution attached to the National University of San Marcos. The museum, located on the university's former site, was established in 1970 with the mission to preserve, study, and exhibit the artistic heritage of the university. Its collections have been organized into four main categories: Portraiture, Popular Art, Contemporary Art, and the Archive of Peasant Painting. The collection of Contemporary Art is rooted in the six versions of the Salones Nacionales de Artes Plásticas that the university organized in the 1950s and 1960s, and from which much of the museum's contemporary collection was gleaned. Since 2010, the MASM organized a campaign to cultivate acquisitions for the contemporary collection growing it in size and profile. 
The museum's strategy focused on encouraging contemporary Peruvian artists to donate their works. Since prioritizing the contemporary collection, the museum has organized two large-scale exhibitions that showcased these acquisitions. ${ }^{6}$ Like the MALI, the MASM's collecting practices of contemporary art and the categories in which the art is sorted are structured through Western stylistic and cultural concerns. For instance, indigenous and vernacular art is not included in the Contemporary collection but are instead classified as Popular art. ${ }^{7}$ This distinction uses museological codes and organizational hierarchies to isolate indigenous and vernacular art inscribing it as "not contemporary". Additionally, the pool of Peruvian contemporary artists that the MASM utilizes to grow its collection is operating within the contemporary art market and production systems.

The MAC (Museum of Contemporary Art) is the newest museum in Lima and was created with the mission to cultivate and present contemporary art. Although the MAC opened in 2013, the origins of the museum reach back to the mid-twentieth century and the IAC (the Institute of Contemporary Art). The IAC, which had multiple, temporary homes, was initially formed around a collection of modern Latin American art, most of which is now split between the collections of the MALI and the MAC. In the 1970s the IAC entered a dormant period, and reinitiated its activities in the 1980s with the decision to build a permanent museum. After a long and fraught process, the museum was finally constructed and opened to the public as the MAC thirty years later. ${ }^{8}$ Significantly, within three months of opening its doors, the MAC hosted the inaugural PArC, one of two significant Limeño art fairs, the other being Art Lima. This was an obvious and strategic attempt by the MAC to develop its collection of contemporary art and raise its profile both regionally and internationally.

The MAC, PARC, and Art Lima emerged during a period after the ten-year rule of authoritarian President Alberto Fujimori (1990-2000) during which there was a focus on the cultural renewal of Lima as, to use Borea's term, "a creative city." In the early twenty-first century, these institutions and events, along with a network of art museums and galleries, worked to articulate Lima's locality as a producer of contemporary art that was also recognized as a significant node within the global art world. To some degree, this has been attained, especially when compared to the equally dynamic, but smaller and more isolated Lima art market of the 1970s, '80s, and '90s (Borea 2016, p. 317).

\section{Legitimizing the Difference: The Category of Latin American Art in the United States}

As a result of these efforts, Peruvian contemporary art has emerged as a visible and active agent in the global art world, and Lima continues shaping itself into a "creative city". This development is generated through neo-liberalization, which is a market-based Western technology of governing that enacts coloniality of power thus reinforcing Western epistemes and Western cultural values. Since the early 2000s, the Museum of Modern Art in New York, the Tate Modern, and the Solomon R. Guggenheim Museum have actively cultivated Latin American contemporary art legitimating it as a category and inserting it into the global/western contemporary art museum system. However, these curatorial and collection-based endeavors attend to Latin American art in so much as it fits and/or follows Western art historical paradigms, which generally excludes indigenous art produced within Latin America. This systemic neglect renders indigenous art invisible to categories of contemporary art.

For instance, the expansive 2014 exhibition Grandes Maestros: Great Masters of Iberoamerican Folk Art curated by Cándida Fernández de Calderón highlighted 800 works of contemporary art from indigenous artists in 22 Latin American countries. The exhibition, which was otherwise a survey of contemporary art, was not shown in a space dedicated to the visual arts, but at the Natural History Museum of Los Angeles County in the United States as well as internationally, thus inscribing its content through an ethnographic lens (Gelt 2014). Parallels can be drawn with the treatment of North

6 On MASM's collection of contemporary art, see (Peralta Berríos 2010; Román 2014).

On MASM's collection of popular art, see (Germana and Yllia 2008).

On the processes and debates surrounding the construction of the MAC, see (Borea 2006, pp. 144-53). 
American indigenous art in the U.S., which is mainly collected and curated within designated folk art institutional and discursive frameworks such as the International Folk Art Festival in Sante Fe, New Mexico and in discipline-specific museums that attend to natural history and folk art.

By excluding Latin American contemporary indigenous art from art historical discourse, curators and museums legitimize this difference. While progressive curatorial efforts have been made to recover Latin American art histories within art museums in the U.S., indigenous art is left out of the dialogue to an almost absurd degree. The 2018 exhibition Pacha, Llaqta, Wasichay: Indigenous Space, Modern Architecture, New Art curated by Marcela Guerrero for the Whitney Museum of American Art explored indigenous notions of architectural and temporal space. The show was Whitney's first deliberately branded Latinx project that boasted inaugural bilingual exhibition texts. Even the exhibition title was rendered in Quechua, the most prevalent indigenous language of the Americas. However, no indigenous artists were included in the exhibition. Instead, it featured a number of Latinx artists working within an indigenismo context or the centuries-old project of indigenous cultural and aesthetic appropriation (Ramos 2019, pp. 122-24). There have been powerful decolonial curatorial efforts within the U.S. such as the 2017 exhibition Radical Women: Latin American Art, 1960-1985 curated by Cecilia Fajardo-Hill and Andrea Giunta and organized by the University of California Los Angeles's Hammer Museum, which presented a hemispheric approach to Latina and Chicana artists who were operating within colonial and patriarchal systems. The exhibition articulated the broader significance of these activist female artists within art historical contexts, but despite its intentions, it still did not include indigenous art.

In her assessment and contextualization of Radical Women, Peruvian curator Florencia Portocarrero argues for the significance of the curators' articulation of an "alternative genealogy [of Latin American Art] which is more coherent with feminist ideals" while acknowledging the problematics of excluding indigenous art production within this new canon (Portocarrero 2019). Peruvian curator Miguel A. López highlighted this contradiction during the symposium associated with the exhibition, asserting that the museal field at large should acknowledge that "curatorial decisions can interrupt or perpetuate the logics of exclusion" and questioning what it would mean for "our curatorial methodologies to include the voices and experiences of Latin American women distinct from the predominantly mestizo and middle-class feminist movement" (Portocarrero 2019). Portocarrero continues López's inquiry by arguing for a self-reflexivity in decolonial practice that involves acknowledging the persistence of coloniality and raciality in shaping the canon of contemporary art even as the processes of "subalternization' of Western aesthetic values develop (Portocarrero 2019).

In contrast, two subaltern curatorial interventions that were solely devoted to indigenous contemporary art practice were recently debuted in the U.S. The exhibitions Resistance and Change: Tablas of Sarhua, Contemporary Paintings from the Peruvian Andes (2019) and Everything That Sounds in the Forest: Contemporary Art of the Peruvian Amazon (2018), exhibited at the University of West Florida's Pensacola Museum of Art, featured the work of indigenous contemporary artists from the Andean and Amazonian regions of Peru. Tablas, curated by Gabriela Germana, featured Andean paintings by Primitivo Evanán Poma and the Asociación de Artistas Populares de Sarhua-ADAPS, as well as works produced by a new generation of Sarhuino painters. The exhibition explored the ways in which Sarhuino artists "reconstructed and reshaped their art and identity by constantly negotiating and reworking their Andean origins and their status as contemporary subjects in a globalized world" (Germana 2019). Everything That Sounds in the Forest, co-curated by Christian Bendayán and Germana, highlighted the diverse production of Amazonian artists and served to open up the otherwise homogeneous perceptions of Amazonian art by displacing it from the discourse of rural, isolated folk art. The resulting exhibition explored themes relating to rural/urban dynamics, local customs and knowledge, and gender and social issues. 


\section{The Peruvian State: Between Nationalist Concerns and the Tourist Market}

The MAC, MALI, and MASM have pursued contemporary art in varied ways, but have ignored the vibrancy of contemporary Peruvian vernacular art and its by-products. As such, the curatorial practices of these institutions, in tandem with the art fairs, have generally negated Peruvian vernacular and indigenous art from the dominant conceptions of contemporary art. In contrast, indigenous and vernacular art has been deployed by Peruvian national cultural institutions throughout the twentieth century in the construction of national identities and have been increasingly associated with tourism and popular art.

Peru, similar to other Latin American countries in the early twentieth century, was enmeshed in the projects of modernization and arguments concerning the definition of the national. The ruling elites of the period, while supporting narratives of economic 'modernization' and 'development,' also promoted narratives of nationhood by deploying archeological objects associated with the pre-Hispanic period and visual art produced by contemporary native people. ${ }^{9}$ These objects resided in state museums and were curated within narrative structures and categorized collections that sought to naturalize the concept of the Peruvian nation as a bound territory that had existed since the beginning of time. These institutions included the National Museum of History (1906), the National Museum of Archaeology (1924), and the National Museum of the Peruvian Culture (1946), which was explicitly dedicated to the vernacular and indigenous arts.

Pre-colonial archaeological objects and contemporary indigenous art were situated, through constructed curatorial narratives, as the past and present material manifestations of the Peruvian nation. As such, indigenous communities were considered the direct descendants of the Inca and other glorious ancient Andean cultures. Indigenismo became a successful ideological and artistic movement that reassessed the identities of the indigenous population within the paradigm of the nation. During the first half of the twentieth century, artists and intellectuals routinely appropriated indigenous artistic production as a means to visualize the abstract concept of Nation. The appropriation of specifically Andean vernacular art by this movement of Indigenist artists trained within the academy and the European system of art grafted a paternalistic vision of the nation to the signifiers of traditional Peruvian art. While the Indigenist artists with a capital "I" played a significant role in visiting and researching native rural artists, acquiring their works, and promoting them in Lima ultimately leading to the establishment of the National Museum of the Peruvian Culture, they also enacted a high-low cultural dichotomy. The Indigenist Movement artists relocated the visual language of native and community artists into the academy, and as a result, the production of community makers became increasingly defined as popular or vernacular art. ${ }^{10}$ These tensions situated traditional artists in a liminal space whereby their work was never fully considered a category of fine art. Instead, it was incorporated into the craft market, and for promotional purposes, a festive and idyllic image of the indigenous was constructed. Marisol de la Cadena asserts, in her study of traditional dances, that this image attracted foreign visitors during a time when tourism was increasing in the country (De la Cadena 2000, pp. 294-301). The celebration of traditional art as a form of "Peruvianness" made this kind of production an attractive commodity for the newly emerging tourist market.

The new focus of traditional art as craft and tourist objects was promoted by the Peruvian government throughout the second half of the twentieth century. This included the establishment of Artesanías del Perú (Handicrafts of Peru) in the 1960s and in 1972 the Empresa Peruana de Promoción Artesanal (Peruvian Company for the Promotion of the Crafts). The intention was to promote Peruvian crafts and their trade at local and international markets. Attached to this was cultural fundamentalism

9 On the embrace of the pre-Columbian past by Latin American elites in the construction of national identities, see (Earle 2007; Yllia 2011). On the use of contemporary indigenousness in the construction of national identities, see (Lopez 2010; Villegas 2006).

10 For discussions of the complex relationship between Indigenist artists and indigenous artistic production, see (Majluf 1994; Villegas 2006; Yllia 2006). 
that linked indigenous people with primitive forms of living, rooted in an ancient Andean culture (most of it an imaginary past), and incapable of dealing with modernity. This image reinforced the use of popular art production as the image of the Nation for intellectual and political discourses and commercial purposes.

The central mission of Peruvian state museums has been to construct and maintain the idea of the nation. Both the Ministry of Commerce and Tourism and the Ministry of Culture's Division of Intangible Heritage continue to promote local and indigenous art. The Director of Intangible Heritage works together with the Museum of National Culture in developing research and exhibition projects on traditional indigenous art from an ethnographic perspective as many of the Peruvian state museums are archaeological, anthropological, or historical museums. None of these institutions attend to the visual arts.

Contemporary indigenous and vernacular art's position within the Peruvian culture-scape is continually framed and reframed by the State and by the collecting and curatorial practices of Limeño cultural institutions. In many ways, the institutional divisions of government agencies and curatorial practices of museums inculcate modernist aesthetic hierarchies and pressure postmodern pluralities that ultimately engage in what Tony Bennett characterizes as a gendered, racialized and classed cultural logic rooted in post-colonial tensions (Bennett 2006, p. 51). However, the museal landscape of Lima is one in which multiple, complex, and contested musealities and conceptions of the contemporary co-exist.

\section{The Agency of Indigenous Artists}

Indigenous contemporary artists' position within Peruvian visual culture is liminal and un-fixed due to the competing, contradictory, and, at times, neglectful curatorial frames of the cultural institutions that present their work in Peru. However, indigenous artists are active agents within these networks. Through complex performativities and appropriations born out of dealing with the forces of tourism and migrations to Lima, indigenous artists negotiate various identities and concepts of contemporary art.

For instance, Andean artists of the Sarhua community traditionally painted symbolic motifs over false beams located on the interior ceilings of traditional dwelling structures. The motifs referred to long-standing Andean religious beliefs and communal structural systems of reciprocity and social cohesion. However, with migration to Lima during the twentieth century, the aesthetic production of the Sarhuino changed. In 1974, two Sarhuino migrant artists, Primitivo Evanán and Víctor Yucra, created a painted beam, which was the first example of this artistic practice being produced outside of Sarhua. They presented the beam in the feast that Sarhuino migrants organized for the anniversary of Sarhua. The feast was attended by the anthropologists Salvador Palomino Flores and Víctor Cárdenas Navarro, who encouraged Evanán and Yucra to continue painting and connected them to Raúl Apesteguía, a collector of folk art and owner of the Huamanqaqa gallery. On 6 August 1975, the first exhibition of Tablas of Sarhua was opened in Apesteguía's space. In addition to two traditional painted beams, the exhibition also included nine paintings produced with synthetic paint instead of the organic pigments typically used and adapted a discrete westernized horizontal panel as a painting support and method of display while depicting idyllic scenes of life in rural Sarhua (Figure 1).

The intention by the artists for these new paintings was to produce decorative objects for sale to an urban public. However, they also functioned as an important cultural expression to make known the history, knowledge, and way of life of their community, as well as to protest the constant injustices suffered. As such, the new Tablas of Sarhua created in Lima had a series of characteristics that made them strategically consumable to viewers allowing them to be easily decoded by the urban public. The innovations made by Evanán and Yucra influenced many Sarhuino painters who reconfigured the visual characteristics and texts of their traditional painted beams and adapted them to Western stylistic conventions, a product of the system in which there were now inserted. This created a new Limeño-Sarhuino style whereby painters began to work in a rectangular format 
that featured narrative scenes, elaborated backgrounds, and interpretive texts. By doing so, the artists appropriated the visual conventions of this system and reworked them according to their own interests (Germana 2015, pp. 253-55). Since the exhibition in Huamanqaqa, traditional and hybridized Tablas of Sarhua were classified as folk and tourist art objects and, until the 2000s, both styles circulated primarily through those two systems.

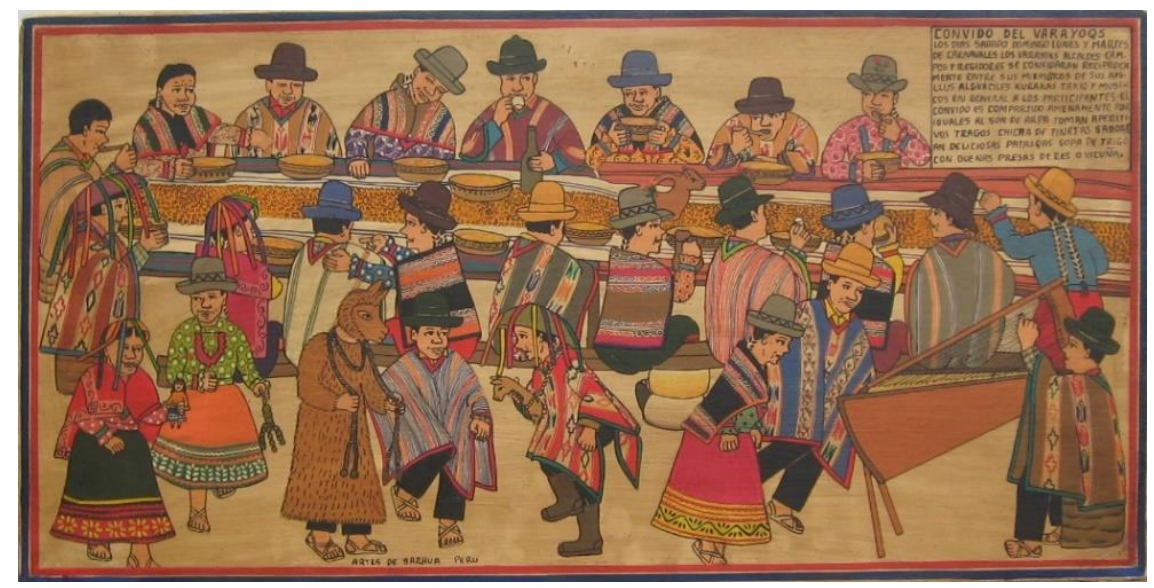

Figure 1. Primitivo Evanán and ADAPS, Convido del Vayayoqs, the 1990s, synthetic paints on board, 40 $\mathrm{cm} \times 60 \mathrm{~cm}$. Collection ADAPS. Photo credit: Gabriela Germana.

In the 1990s Sarhuino artists also engaged in social critiques and produced two painting series: Piraq causa (Who is to blame? 1990-1992) that narrates the events that took place in the community of Sarhua during the Peruvian internal war, and Éxodo (Exodus, 1994-1995) that narrates the traumatic experiences of the Sarhuino migration to Lima throughout the twentieth century. Significantly, the series garnered the attention of the Limeño art system. In 2010, art historian, critic, and curator Buntinx bought Éxodo for his Micromuseo collection after which art historian and curator Germaná commissioned the painters to create a new series about migration (Katkakatay/Trembling) for the show Lima04 at the MAC (2013), and finally, the Croatian curatorial collective What, How and for Whom/WHW commissioned the artists to produce a new series titled Discriminación (Discrimination) for the exhibition Very Useful Knowledge at the Museum Reina Sofia in Madrid (2014). Moreover, in 2017, the series Piraq Causa, which had been acquired for the collection of Con/Vida-Popular Arts of the Americas (Detroit, Michigan), was donated by that institution to the MALI, and after being evaluated by the CAAC (Contemporary Art Acquisition Committee), the works were accessioned into the MALI contemporary art collection in 2018. It was the first time a work previously categorized as folk art was acquired for a collection of contemporary art in Peru, but only after it circulated through institutional ownership in the U.S. In 2019, the contemporary art gallery Ginsberg decided to represent Primitivo Evanán and his daughter Valeriana (as the Evanán Workshop), and Venuca Evanán exhibiting their works in the international contemporary art fairs Arco Madrid and Art Lima (Figure 2).

The painters of Sarhua, however, continue to conceptualize the Tablas as part of a larger cultural tradition and, in the 2010s, they requested the Ministry of Culture's Division of Intangible Heritage to recognize the Tablas as cultural heritage of the nation. In 2018, this official recognition was granted. Additionally, the artists requested the UNESCO office in Lima to support a series of projects, which led to the implementation of the "Sarhua Initiative" that promoted the cultural expressions of the community. Likewise, the Ministry of Tourism continues to support Sarhuino painters in making their work more saleable on the tourist market. As such, the painters of Sarhua are active cultural agents, 
who are constantly negotiating different regimes of value ${ }^{11}$ by reworking their Andean origins and their most recent history as contemporary subjects in a globalized world.

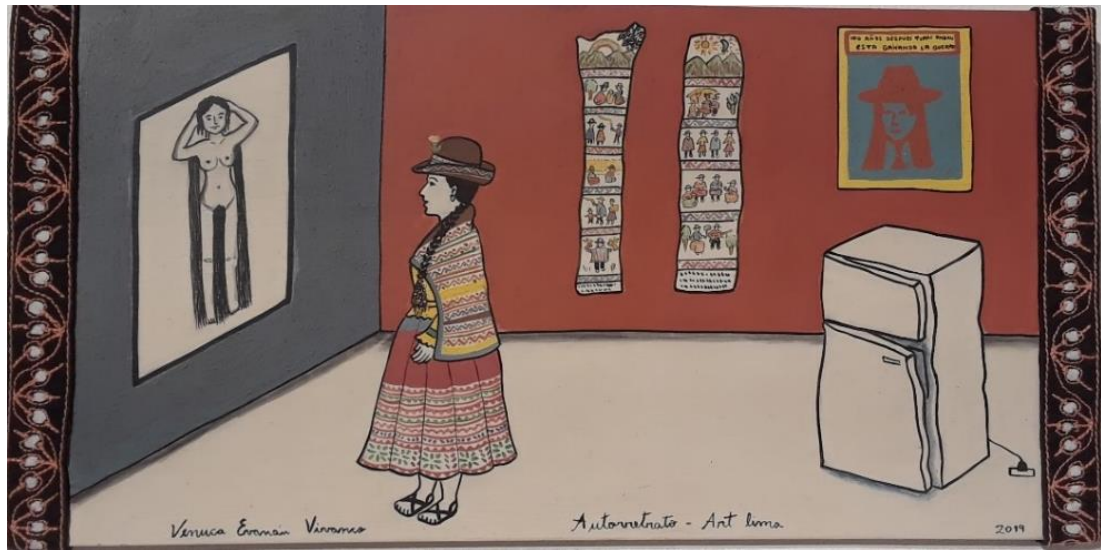

Figure 2. Venuca Evanán, Autoretrato-Art Lima, 2019, natural pigments on board, $20 \mathrm{~cm} \times 36 \mathrm{~cm}$.

Collection of the artist. Photo credit: Gabriela Germana.

Similar negotiations of indigenous and western aesthetic styles occur with Amazonian artists. The Bora and Huitoto ethnic groups, which traditionally produced wearable art and body art based in geometric symbolic motifs, began producing figurative scenes over a westernized two-dimensional painting support. Peruvian art historian Yllia (2009) argues that the establishment of Western-oriented schools in the area in the 1930s taught hegemonic discourses, patterns, and codes of Western culture that cultivated generations of native artists painting in a Western-style and format. Tourism was another critical agent of change that peaked in the 1970s. At that time, the Peruvian government helped the Bora and Huitoto organize folkloric groups to present their dances for tourist consumption while Bora and Huitoto visual artists produced paintings depicting their rituals and everyday scenes, as well as the elements of the natural environment for the tourist market.

During the late twentieth century, three Bora and Huitoto painters, Víctor Churay, Rember Yahuarcani, and Brus Rubio migrated to Lima. The artists developed specific hybridized styles that allowed them to succeed in Lima's contemporary art system while still referring to their native culture. Churay, the first to arrive in Lima, produced a work on the Bora worldview based on hallucinogenic visions using acrylic paint, which allowed him to enrich his palette and experiment with contrast and brilliant colors (Yllia 2017, p. 389). Yahuarcani's work relies on Huitoto mythology, but his materials and stylistic choices became hybridized according to Borea (2010). After painting with natural pigments on llanchama, Yahuarcani experimented with acrylic paints "while choosing to focus on one or two mythological characters rather than depicting the myth" (Borea 2010, p. 75). He began painting on canvas, allowing him to work in bigger formats and used neutral backgrounds for his mythological characters (Figure 3). Rubio's work attends to Huitoto customs and worldview, to which he has added social, historical, and political issues that have affected his community, as well as his own experiences in the contemporary art system and different cities around the world. Currently, Yahuarcani and Rubio show their works at influential art galleries in Lima, and in art institutions around the world.

11 Term used by Arjun Appadurai to analyze the way objects are given certain values within a specific cultural context (Appadurai 1986). 


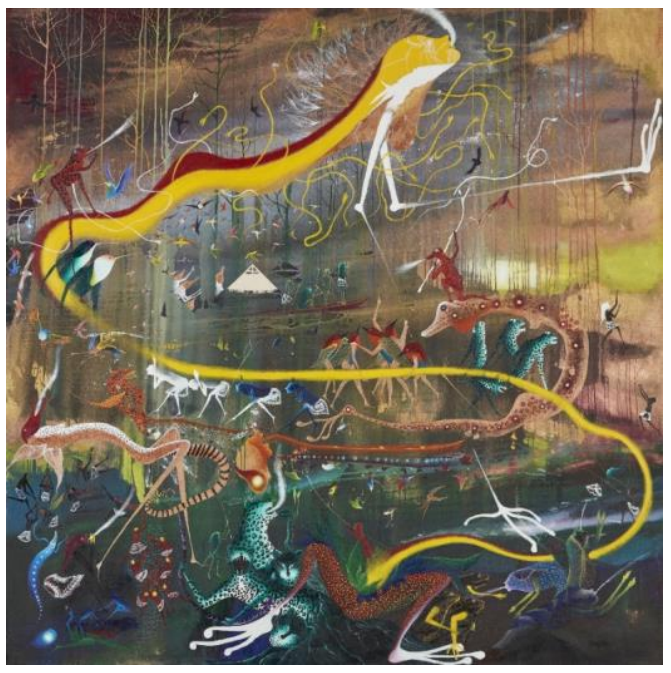

Figure 3. Rember Yahuarcani, Los primeros humanos conquistan a la mujer Arco Iris, la acomodan para que el cielo no caiga a la tierra, 2017, acrylic on canvas, $170 \mathrm{~cm} \times 170 \mathrm{~cm}$. Collection Museo Central-Banco Central de Reserva del Perú. Photo: Courtesy of Museo Central-Banco Central de Reserva del Perú.

Artists from other Amazonian ethnic groups have also successfully navigated the Limeño contemporary art system in recent years. Among them, the Shipibo-Konibo painters Elena Valera and Roldán Pinedo. During the 1980s, many Shipibo-Konibo migrated to Lima due to the impacts of the Peruvian internal armed conflict. Similar to the Bora and Huitoto, the Shipibo-Konibo traditionally produced utilitarian art decorated with geometric symbolic motifs. Due to requests by multiple scholars, Valera began depicting the myths and customs of her community in a realistic figurative style garnering visibility in the Lima art system. Critically, Valera produced a series of paintings in which she depicted the process of migration of the Shipibo-Konibo and contrasted their traditional way of living with their new life in the city (Germana 2013, pp. 42-44) (Figure 4). Among the Shipibo-Konibo, painting is customarily a female practice. In Lima, however, as gender roles shifted, some male members of the community began to paint in the new figurative style. Pinedo is one such male artist who is recognized for his paintings of the animals that populate the Amazon rainforest. Valera and Pinedo have also exhibited their paintings in important Limeño art institutions.

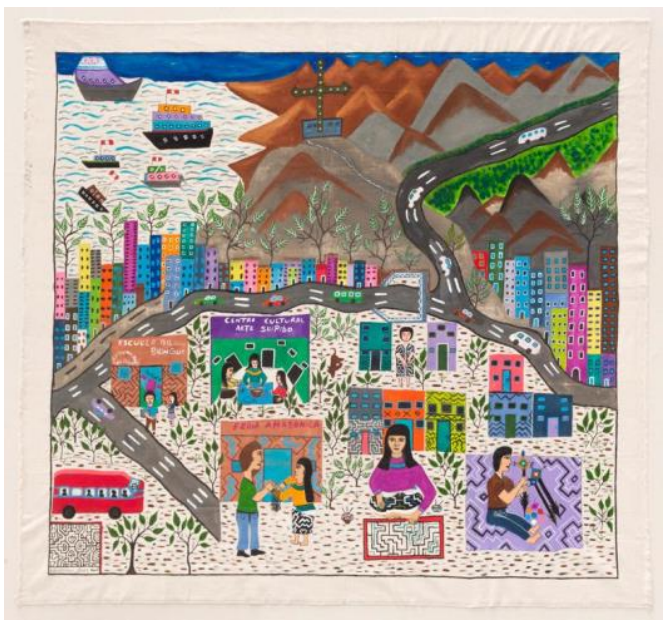

Figure 4. Elena Valera, La comunidad Shipibo-Conibo de Cantagallo (Lima), 2012, acrylic paint on cloth, 118 $\mathrm{cm} \times 110 \mathrm{~cm}$. Photo credit: Juan Pablo Murrugarra. Courtesy of MAC Lima. 


\section{Alternative Curatorial Practices and Musealities}

Driven by the "creative adaptations" of contemporary indigenous artists, independent curators in Lima have organized important exhibitions in the twenty-first century that contest the hierarchical divisions which have systematically negated Peruvian vernacular and indigenous art from dominant conceptions of the contemporary. Curators Gredna Landolt and Christian Bendayán have created openings for Amazonian artists to enter into contemporary art discourses. In the early 2000s, Landolt curated two large exhibitions that brought decisive visibility to Amazonian art production in the Limeño art system: El Ojo Verde. Cosmovisiones Amazónicas (2000-2001), and Serpiente de Agua. La Vida Indígena en la Amazonía (2003) (Borea 2010, pp. 70-71). Both exhibitions presented large groups of paintings developed by different Amazonian indigenous artists that depicted the myths and worldviews of their communities exhibited alongside besides more traditional objects.

Bendayán, an artist born in Iquitos, a key city in the Peruvian Amazon, migrated to Lima, where he now resides. His curatorial practice in the city actively highlights the diversity of contemporary artists, including native, urban, and even non-Peruvian artists, all of whom engage with the diverse aspects of the Peruvian Amazon. Through exhibitions such as La Soga de los Muertos (2005), La Piel de un Río: La Amazonía en el Arte Contemporáneo (2008), Poder Verde. El desborde Amazónico (2009) (Figure 5), or Las semillas de los dioses. Arte enteogénico en la Amazonía peruana (Rusia, 2018) Bendayán has provided a decolonial perspective of the Peruvian Amazon by breaking the stereotyped vision that presents the Amazon as an idyllic natural place without considering the complexities of a space where nature, ancient indigenous practices, and modernity coexist. Between 2015 and 2018, Bendayán founded and directed the project "Bufeo/amazonía + arte" that was devoted to the research, promotion, and management of Amazonian art. During these years, Bendayán developed the category of "Amazonistas" to refer to and value the Amazon region "como un espacio para investigar y pensar al país en su conjunto. No corresponde a una categoría cerrada y homogénea, sino más bien a un nuevo y múltiple espacio de exploración para artistas cautivados por las visiones, la cosmovisión, la historia y las narrativas alternas, la selva urbana y su promiscua modernidad, el misticismo y la conservación de este territorio pródigo" (Bendayán 2017, pp. 12-13). ${ }^{12}$

Besides group shows, solo exhibitions by Amazonian artists in art museums and galleries have consolidated their presence in the Limeño contemporary art system. Although painters continue referring to their worldview and sometimes to their traditional ways of living, the focus of these exhibitions has been on the aesthetic characteristics of the works and the particular stylistic qualities of each artist. In 2005, Landolt curated the exhibition Esta es Nuestra Costumbre of Shipibo artists Valera and Pinedo in the Art Museum of San Marcos.In 2008, artist and curator Armando Williams presented the exhibition of Huitoto painter Yahuarcani Llanchama: Sólo pieles in the contemporary art gallery 80 $\mathrm{m}^{2}$. In 2009, Borea and curator David Flores Hora organized the exhibition Once Lunas by Huitoto artists Santiago y Rember Yahuarcani in the art gallery Pancho Fierro of the Municipality of Lima. In 2009, Bendayán curated La selva invisible by Huitoto artist Rubio in the Visual Arts Gallery of the University Ricardo Palma. In 2014, art historian María Eugenia Yllia curated the exhibition Presente of Shipibo artist Pinedo in the art gallery of Fundación Euroidiomas, and in 2017 the exhibition BIN+E $R E+K+$ Tizón de este mundo. El tabaco del abuelo tigre by Rubio.

12 "As a space to investigate and think of the country as a whole. It does not correspond to a closed and homogeneous category, but rather, to a new and multiple space of exploration for artists captivated by the visions, the worldview, history and alternate narratives, the urban jungle and its promiscuous modernity, mysticism and the conservation of this prodigal territory" (Bendayán 2017, pp. 12-13, our translation). 


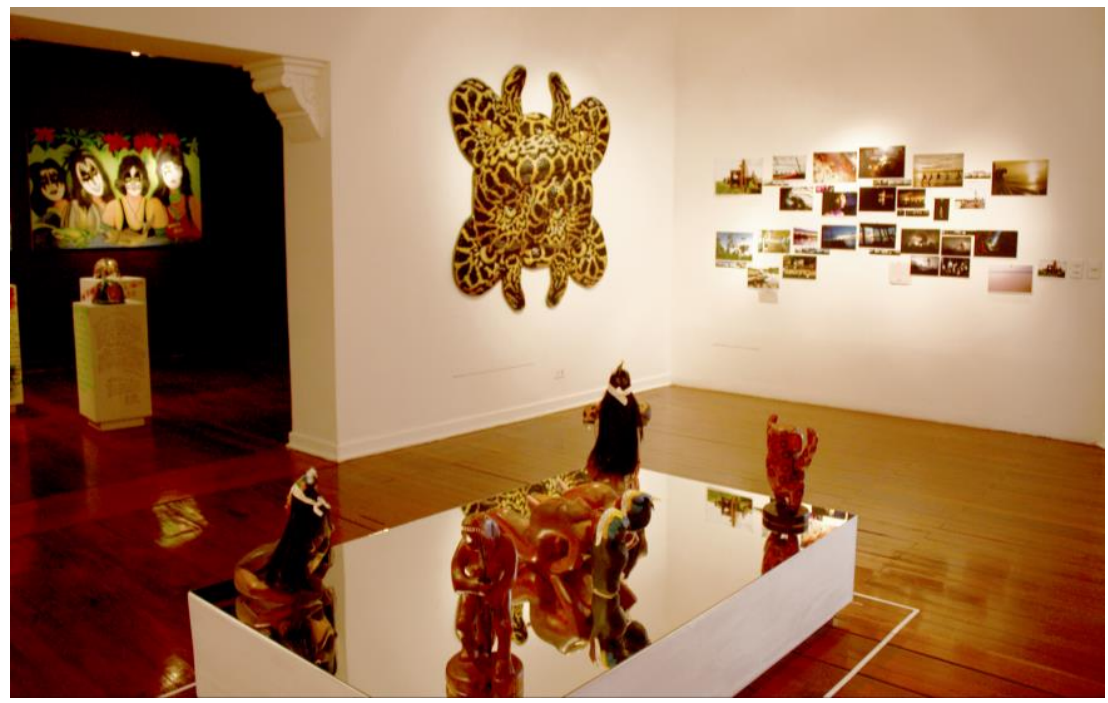

Figure 5. Poder Verde: El desborde amazónico installation view. Photo: Christian Bendayán. Courtesy: Christian Bendayán.

Other independent curators have tried to contest the hierarchical divisions established by the system of Peruvian contemporary art by working on Andean indigenous art. In 2006, anthropologist César Ramos curated Manos Artesanas: 20 miradas para un nuevo imaginario ciudadano in the San Marcos Art Museum. The exhibition showcased a group of works that Ramos commissioned pairing 20 urban artists with 20 rural artists or "artist artisans" as he referred to them. In 2008, art historian Germana and anthropologist Borea curated Grandes maestros del arte peruano: Mérida, Rojas, Urbano, Sánchez. The curators highlighted four Andean artists who were categorized as folk artists, and through that label, were viewed as embodiments of ancient and static Andean traditions. However, the exhibition, which traveled to art galleries and art museums in the cities of Cusco, Ayacucho, and Lima, presented the multivalency of the artists as producers of contemporary culture rooted in Andean aesthetic traditions. In 2011, Germana and Buntinx curated an exhibition on the history of the Tablas of Sarhua titled Éxodo/Llaqta Puchukay. Historias de migración y violencia en las pinturas de Sarhua in the art gallery Pancho Fierro of the Municipality of Lima, and the exhibition Tabla Apaykuy. Herencia cultural andina $y$ ciudadanía en las pinturas de Sarhua curated by art historian Issela Ccoyllo for the art gallery Euroidiomas that highlighted the individual work of Primitivo Evanán and his daughter Venuca Evanán. In 2013, Germana curated Entornos reconfigurados, a section within the larger Lima04 exhibition organized by the MAC. Entornos reconfigurados took as its premise the large migrations from the rural areas of Peru to the capital city that occurred during the second half of the twentieth century. Germana selected four artists, two first-generation migrants and two second-generation migrants of which the latter pair trained at the National School of Fine Arts. The artists produced works that offered different perspectives on migration rooted in their own lived experiences. Significantly, Entornos reconfigurados was the first time the MAC had shown works of indigenous artists.

The critic and curator Buntinx is an especially important figure in Peru. His record of curatorial projects has commonly addressed the complex negotiation of museological practice within the context of political and social unsteadiness by enacting a decolonial approach to framing Peruvian contemporary art. For example, Buntinx's 'Micromuseo', an alternative museotopic project, is a mobile museum inspired by the 'micro', a form of popular public transportation characteristic of Lima that is representative of the popular urban culture and functions as a sign of alternative modernities. Most significantly, he curated the exhibition Museum Void: Half a Century of Peruvian Museotopies (1966-2016) at the MAC mentioned at the beginning of this article. With the exhibition, Buntinx contested Western museal paradigms by interrogating the absence of a museum for contemporary art in Lima as a form of presence that has prompted Peruvian, and specifically Limeño, artists to articulate negotiations of 
their national, global, and decolonial identities through the museal frame (Bowman-Mc-Elhone and Germana 2016, pp. 411-20). Included in the exhibition was Fernando Bryce's Museo Hawai, which combines wildly divergent contemporary Peruvian objects and printed images in order to subvert the exoticized and othered manner in which Peruvian culture is represented in museums, and Giuseppe Campusano's Museo Travesti del Perú, which proposes a new reading of Peruvian history rooted in traditions of drag and masquerade through a timeline ranging from the pre-Hispanic past through the present that concludes with Campusano himself, thus contesting the canon used by museums to construct history and memory (Figure 6). ${ }^{13}$

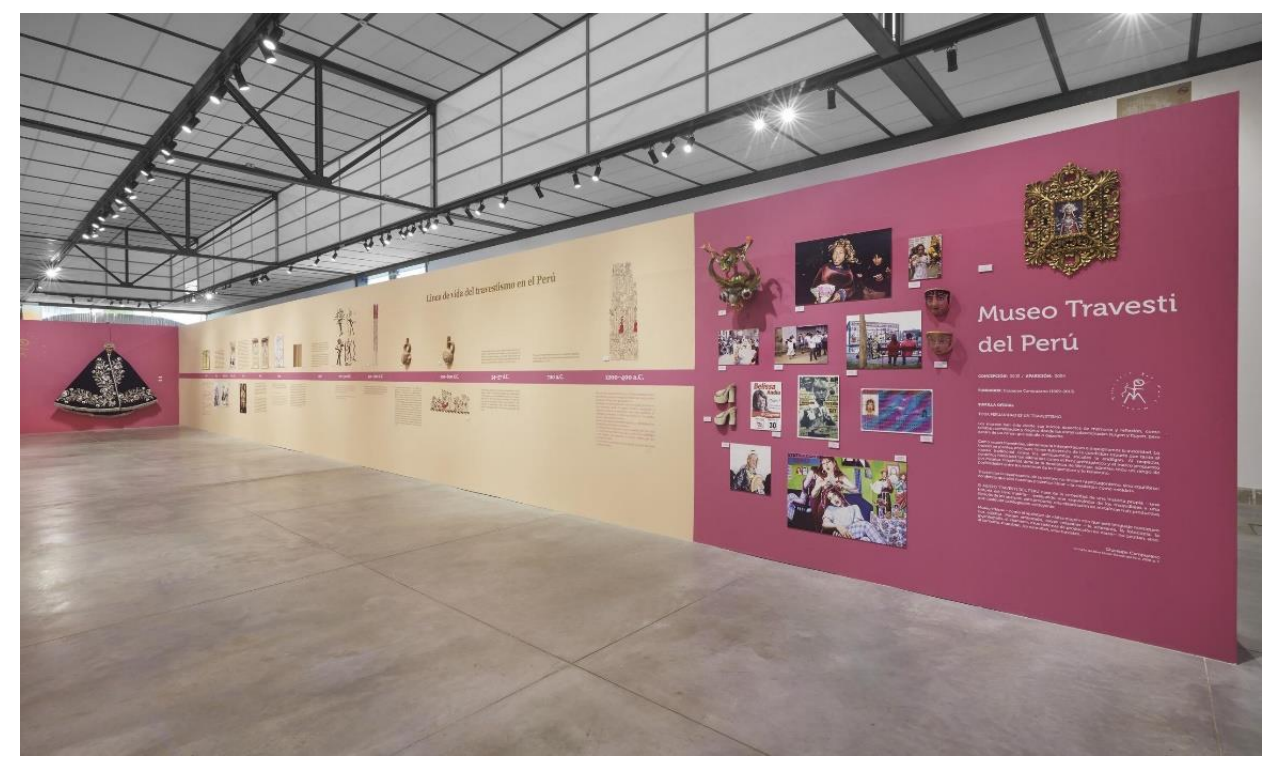

Figure 6. Giuseppe Campusano, Museo Travesti del Perú (2003). Museum Void: Half a Century of Peruvian Museotopies (1966-2016) installation view. Photo: Juan Pablo Murrugarra. Courtesy of MAC Lima.

With the exhibition, Buntinx is at once questioning the MAC's ability to fill the museum vacancy by implicating it as a paradigmatic Western institution while also bolstering the institutional legitimacy of the new museum within the city by simultaneously housing, equating, and co-opting the agency of these alternative, decolonial, museotopic works. Ultimately, the collection of museotopias and the narrative of their histories presented in 'Vacio Museal' attempts to fill a museum emptiness, but, as a collection, they also suggest something more interesting. By reaching to negate a void in Peruvian culture, these works present other avenues to negotiate the global contemporary artistic system by providing compelling alternatives, framed through museum practice, to understanding contemporary art and the different contemporaneities in Peruvian culture (Bowman-Mc-Elhone and Germana 2016, pp. 411-20).

\section{Conclusions}

As of 2019, the MALI, MASM, and the MAC are among the primary museums of contemporary art in Peru. Although their collections of contemporary art and curatorial aims are still rooted in the global Euro-American framework of contemporary art, there has been marked progress. For instance, the MASM has stated its intention to curate a single exhibition that combines and features its collections

13 For a review of the exhibition, see (Bowman-Mc-Elhone and Germana 2016). 
of contemporary and popular art ${ }^{14}$, and the MAC has hosted exhibitions such as Lima04 and Museum Void. More interestingly, however, is the new perspective that the MALI has adopted since 2018. While in 2014, the museum did acquire a group of paintings by Huitoto artist Rember Yahuarcani for its collection of contemporary art, it was not until 2018, with its acquisition of the series of Sarhuino paintings Piraq Causa, that the MALI began to critically reconsider its perspective on contemporary art. As a consequence, in 2019, the museum opened the temporary exhibition Otras historias posibles: Repensando las colecciones del MALI (Other possible stories: Rethinking MALI collections), which intended to explore "algunos de los ejes claves de la cultura visual desde las colecciones del museo: Diseño gráfico, retrato fotográfico y las llamadas 'artes populares'. De esta forma, se busca repensar los límites y categorías que tradicionalmente han guiado la discusión sobre lo que constituye el arte peruano" (MALI 2019). ${ }^{15}$

Through new curatorial strategies and discourses in Lima as enacted by indigenous and vernacular artists and by independent curatorial agents as "creative adaptations" and new musealities, the Peruvian art scene has opened to broader ideas of difference. The MALI, MASM, and MAC, along with other institutions, are incorporating and internalizing these decolonial perspectives by acknowledging the complex configuration of Peruvian society and its different and alternative modernities. In so doing, Peruvian contemporary art institutions are leaving the narrative of monolithic Western modernism behind and are articulating alternative musealities that witness the specificities of Peruvian contemporary art production in dialogue with indigenous and vernacular artists and their conceptions of the contemporary.

Author Contributions: All authors contributed equally to this manuscript. All authors have read and agreed to the published version of the manuscript.

Funding: This research received no external funding.

Conflicts of Interest: The authors declare no conflict of interest.

\section{References}

Appadurai, Arjun. 1986. Introduction: Commodities and the politics of value. In The Social Life of Things: Commodities in Cultural Perspective. Cambridge: Cambridge University Press, pp. 3-63.

Bendayán, Christian. 2017. Amazonistas. Lima: Bufeo/Amazonia+Arte.

Bennett, Tony. 2006. Exhibition, Difference, and the Logic of Culture. In Museum Frictions. Edited by Ivan Karp. Durham: Duke University Press, pp. 46-69.

Bhambra, Gurminder K. 2014. Postcolonial and decolonial dialogues. Postcolonial Studies 17: 115-21. [CrossRef]

Borea, Giuliana. 2006. Museos y Esfera Pública: espacios, discursos y prácticas. Reflexiones en torno a la ciudad de Lima. In Mirando la Esfera Pública Desde la Cultura en el Perú. Edited by Gisela Cánepa and María Eugenia Ulfe. Lima: Concytec, pp. 133-68.

Borea, Giuliana. 2010. Personal cartographies of a Huitoto mythology: Rember Yahuarcani and the enlarging of the Peruvian contemporary art scene. Artigos. Revista de Antropologia Social dos Alunos do PPGAS-UFSCar 2: $67-87$.

14 Germán Carnero Roqué, director of the MASM between 2006 and 2016, stated that along with the permanent exhibitions of the collection of portraits, and of contemporary art, the museum was going to show permanently the collection of Popular Art, "sin que dejemos de considerar la posibilidad de fusionar en un futuro, en una sola muestra de 'arte contemporáneo', los trabajos de los artistas del llamado 'arte popular' con la plástica de los creadores del llamado 'arte moderno o contemporáneo'." (Without ceasing to consider the possibility of merging in a future, in a single exhibition of 'contemporary art', the works of the artists of the so-called 'popular art' with the plastic of the creators of the so-called 'modern or contemporary art') (Carnero Roqué 2016, p. 13). In 2016, the philosopher and art critique Augusto del Valle was appointed as new director of the MASM, however, he has not made any statement about the museum collections.

15 "Some of the key axes of visual culture from the museum's collections: graphic design, photographic portrait and the so-called "popular arts". In this way, it seeks to rethink the limits and categories that have traditionally guided the discussion about what constitutes Peruvian art" (MALI 2019, our translation). 
Borea, Giuliana. 2016. Fueling museums and art fairs in Peru's capital: the work of the market and multi-scale assemblages. World Art 6: 315-37. [CrossRef]

Bowman-Mc-Elhone, Amy, and Gabriela Germana. 2016. Vacío Museal: Medio siglo de museotopías peruanas (1966-2016), curated by Gustavo Buntinx, Museo de Arte Contemporáneo de Lima, 24 June-25 September. Journal of Curatorial Studies 5: 411-15. [CrossRef]

Carnero Roqué, Germán. 2016. Presentación. In Herencias y Tradiciones. Colección de Arte Popular del Museo de Arte de San Marcos. Lima: Fondo Editorial del Congreso del Perú, p. 13.

Chatarjee, Partha. 1997. Our Modernity. Rotterdam and Dakar: SEPHIS-CODESRIA.

Contreras, Carlos, and Marcos Cueto. 2013. Historia del Perú Contemporáneo. Lima: Instituto de Estudios Peruanos.

De la Cadena, Marisol. 2000. Indigenous Mestizos: The Politics of Race and Culture in Cuzco, Peru, 1919-1991. Durham: Duke University Press.

Earle, Rebecca. 2007. The Return of the Native: Indians and Myth-Making in Spanish America, 1810-1930. Durham: Duke University Press.

Gaonkar, Dilip Parameshwar. 1999. On Alternative Modernities. Public Culture 11: 1-18. [CrossRef]

Gelt, Jessica. 2014. Folk Art with a Twist in 'Grandes Maestros' at Natural History Museum. Los Angeles Times, November 1. Available online: https://www.latimes.com/entertainment/arts/la-et-cm-ca-grandes-maestros20141102-story.htm (accessed on 1 October 2019).

Germana, Gabriela. 2013. Entornos reconfigurados. Tránsitos artísticos en la nueva contemporaneidad limeña. In Lima04 [Exh. Cat.]. Lima: Museo de Arte Contemporáneo de Lima, pp. 36-47.

Cécile, Michaud. 2015. Tablas pintadas de Sarhua. La apropiación y reelaboración de construcciones visuales y escritas para la representación y transmisión de discursos sobre ritos, tradiciones y conflictos sociales. In Escritura e Imagen en Hispanoamérica. De la Crónica Ilustrada al Comic. Cécile, Michaud. Lima: PUCP, pp. 243-69.

Germana, Gabriela. 2019. Resistance E Change: Tablas of Sarhua, Contemporary Paintings from the Peruvian Andes. Pensacola: Pensacola Museum of Art, Available online: https://www.pensacolamuseum.org/resistance-change-tablas-of-sarhua-contemporary-paintings-from-the-peruvian-andes.html (accessed on 1 October 2019).

Germana, Gabriela, and María Eugenia Yllia. 2008. Miradas Alternas: Visiones y Discursos en la Colección de Arte Popular del MASM. Lima: Museo de Arte de San Marcos.

Latham, Kiersten F. 2017. The Laboratory of Museum Studies: Museality in the Making. Journal of Education for Library and Information Science 58: 219-35. [CrossRef]

Lerner, Sharon, ed. 2013. Arte Contemporáneo: Colección Museo de Arte de Lima. Lima: Asociación Museo de Arte de Lima MALI.

López, Sinesio. 1997. Ciudadanos Reales e Imaginarios. Concepciones, Desarrollo y Mapas de la Ciudadanía en el Perú. Lima: Instituto de Diálogo y Propuestas.

Lopez, Rick. 2010. Crafting Mexico: Intellectuals, Artisans, and the State after the Revolution. Durham: Duke University Press.

Majluf, Natalia. 1994. El indigenismo en México y Perú: Hacia una visión comparativa. In Arte, Historia e Identidad en América: Visiones Comparativas. Edited by Gustavo Curiel, Renato González Mello and Juana Gutiérrez Haces. Ciudad de México: Universidad Nacional Autónoma de México-Instituto de Investigaciones Estéticas, pp. 611-28.

MALI. 2019. Otras Historias Posibles. Repensado las Colecciones del MALI. Available online: http://www.mali.pe/ expo_detalle.php?id=159\&p=ant\&anio=2019 (accessed on 1 October 2019).

Matos Mar, José. 1984. Desborde Popular y Crisis del Estado. El Nuevo Rostro del Perú en la Década de 1980. Lima: Instituto de Estudios Peruanos.

Mignolo, Walter. 2011a. It Is 'Our' Modernity: Delinking, Independent Thought, and Decolonial Freedom. In The Darker Side of Western Modernity: Global Futures, Decolonial Options. Durham: Duke University Press, pp. 118-45. [CrossRef]

Mignolo, Walter. 2011b. Preface and Acknowledgments. In The Darker Side of Western Modernity: Global Futures, Decolonial Options. Durham: Duke University Press, pp. XI-XXXVII. Available online: https://read.dukeupress. edu/books/book/1582/chapter/175667/Preface-and-Acknowledgments (accessed on 1 October 2019).

Peralta Berríos, Juan, ed. 2010. Colección de Arte Contemporáneo. Museo de Arte de la Universidad Nacional Mayor de San Marcos. Lima: Museo de Arte del Centro Cultural de San Marcos. 
Portocarrero, Florencia. 2019. Radical Women: A New Genealogy for Latin American Art. Atlántica. 60. Available online: http://www.revistaatlantica.com/en/contribution/mujeres-radicales/ (accessed on 1 October 2019).

Quijano, Aníbal. 1980. Lo Cholo y el Conflicto Cultural en el Perú. Lima: Mosca Azul Editores.

Ramos, Horacio. 2019. On Representation, Appropriation, and Everything in between. Shift 11: 122-24. Available online: https://shiftjournal.org/wp-content/uploads/2019/02/10.-Ramos-Shift-11.pdf (accessed on 1 October 2019).

Román, Élida. 2014. Colección de Arte Contemporáneo del Museo de Arte de San Marcos-Tomo II. Lima: Museo de Arte del Centro Cultural de San Marcos.

Villegas, Fernando. 2006. El Instituto de Arte Peruano (1931-1973): José Sabogal y el mestizaje en arte. Illapa 3: 21-34. [CrossRef]

Yllia, María Eugenia. 2006. El mate mestizo de José Sabogal. In El Fruto Decorado. Mates Burilados del Valle del Mantaro. Lima: Instituto Cultural Peruano Norteamericano-Universidad Ricardo Palma, pp. 45-55.

Yllia, María Eugenia. 2009. De la maloca a la galería: La pintura sobre llanchama de los boras y huitotos de la Amazonía peruana. Illapa 6: 95-107. [CrossRef]

Yllia, María Eugenia. 2011. Quimera de piedra: Nación, discursos y museo en la celebración del centenario de la Independencia (1924). Illapa 8: 101-20. [CrossRef]

Yllia, María Eugenia. 2017. Antropófagos contemporáneos: paradojas y logicas visuales en la pintura amazonica contemporanea peruana. In Arte y Antropología. Estudios, Encuentros y Nuevos Horizontes. Edited by Giuliana Borea. Lima: Pontificia Universidad Católica del Perú, pp. 387-95.

(C) 2020 by the authors. Licensee MDPI, Basel, Switzerland. This article is an open access article distributed under the terms and conditions of the Creative Commons Attribution (CC BY) license (http://creativecommons.org/licenses/by/4.0/). 